Acta Technologica Agriculturae 2

Nitra, Slovaca Universitas Agriculturae Nitriae, 2019, pp. 56-59

\title{
TITANIUM AND STAINLESS STEEL MIG LSC WELDING
}

\author{
Nela POLÁKOVÁ*, Petr DOSTÁL \\ Mendel University in Brno, Czech Republic
}

\begin{abstract}
This paper deals with the issue of welding two different materials - titanium and stainless steel (UNS N50400 + X5CrNi 18-10). These two materials have completely different chemical compositions and mechanical properties; therefore, process of their mutual welding is complicated. Melting temperature of both materials is also different. An innovative MIG LSC arc welding method with an additional material has been selected for this purpose. A protective atmosphere was used in order to avoid galvanic corrosion of materials that would preclude the welding process. Aforementioned atmosphere contained $100 \%$ Ar. The MIG LSC welding method was designed by Fronius. Presented experiment compares utilization of following 4 different electrodes (additional material) for the welding of titanium and stainless steel: Ti, Fe, corrosion-resistant Fe and CuSi3 electrode. Tensile test was utilized for evaluation of weldment mechanical properties. Measured results were supplemented with a metallographic analysis snapshot and tensile diagram.
\end{abstract}

Keywords: welding; titanium; stainless steel; MIG LSC; CuSi3 welding electrode

Multiple industries, such as nuclear industry, are interested in welding of two different corrosion-resistant materials: stainless steel and titanium. Titanium and stainless steel cannot be welded reliably, because these materials are characteristic by mutual metallurgical incompatibility. This is due to the formation of brittle intermetallic compounds that arise when titanium is welded with stainless steel (Pardal et al., 2016). Ability to create a heterogeneous weld of different metals is determined by their weldability. Fusion welding involves mixing of basic materials (possibly with additional material). Problems associated with fusion welding of titanium were observed by e.g. Sagar et al. (2018). Weldability is a term that indicates the ability of a particular material (metal) to form a weld. Weld is used to join the material (Hluchý and Kolouch, 2002). Weld can be made using a combination of high temperature required to melt the material and necessary pressure. Issue of weldment quality created by arc welding was observed by Hluchý et al. (2002). Welding process includes three phases: melting phase, solidification phase and cooling phase, which it easiest to carry out. If materials characteristic with guaranteed weldability or reduced weldability (this information is given by the material manufacturer) are welded, it is advisable to weld them by means of an electrode welding process with an additional electrode (Černý et al., 2016a). Variety of corrosion complications tends to occur during welding. However, with the development of new technologies, operational parameters, and new aggressive substances, these combinations become increasingly complex. Problems caused by corrosion of metals and welds adversely affect industrial development. They cause considerable damage, so it is important to pay attention to corrosion and eliminate it as much as possible (Šustr et al., 2016). For the aforementioned reasons, it is advisable to use corrosion-resistant metal materials. However, corrosion affects not only metals, but also non-metallic materials (corrosion of concrete, glass and plastics). Material protection against corrosion can be ensured in numerous different ways. The most common method for protection of materials against corrosion, especially metal, includes the usage of a protective surface (e.g. paint), correcting the corrosive environment (a complex solution in some cases). The most reliable protection lies in selection of a suitable material (Talbot and Talbot, 2019). Considering the welding of corrosion-resistant materials, it is also necessary to select a suitable protective atmosphere.

\section{Material and methods}

Purpose of theexperiment wastofind outa suitableadditional material in order to create a heterogeneous weldment using the MIG LSC method. Two basic materials (difficult to weld together) were welded - UNS N50400 titanium and X5CrNi 18-10 stainless steel. These basic materials were selected because of their complex welding process and need for joining these two materials for the purposes of nuclear and chemical industries. All in all, 4 different electrodes in total were gradually used for welding. Each electrode was used for welding of 10 samples. Consequently, 40 samples were welded and subsequently analysed. Table 1 shows two basic materials and their chemical composition.

Contact address: Nela Poláková, Mendel University in Brno, Faculty of AgriSciences, Department of Technology and Automobile Transport, Zemědělská 1, 61300 Brno, Czech Republic, e-mail: nela.polakova@mendelu.cz 
Table $1 \quad$ Basic materials

\begin{tabular}{|l|c|c|}
\hline Basic material 1 & Titanium Grade 2 (UNS N50400) & $\begin{array}{c}\text { Ti 99.375\%; Fe max. 0.25\%; O max. 0.25\%; C max. 0.08\%; } \\
\text { N max. 0.03\%; H max. 0.015\%; Density 4.51 g.cm }\end{array}$ \\
\hline Basic material 2 & Austenitic chromium-nickel steel (X5CrNi18-10) & $\begin{array}{c}\text { Fe 68.805\%; Cr 18\%; Ni 10\%; C 0.12\%; Mn 2\%; Si 1\%; } \\
\text { P 0.045\%; S 0.03\% }\end{array}$ \\
\hline
\end{tabular}

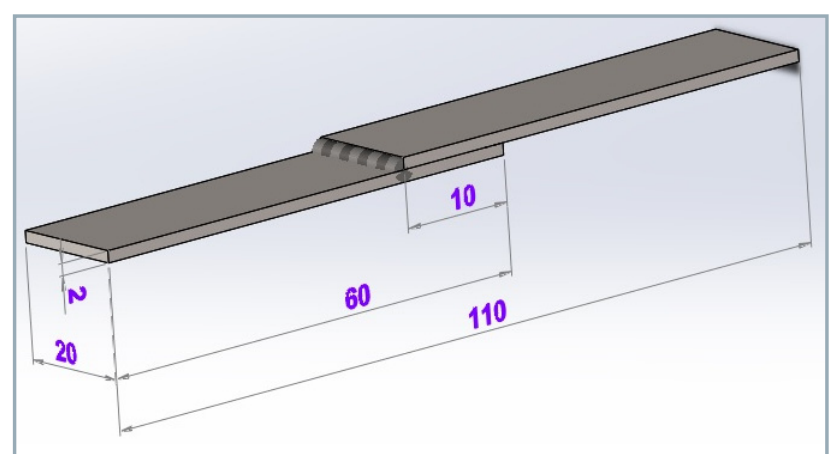

Fig. 1 Dimensions of welded samples

Titanium Grade 2 (UNS N50400) supplied by the Bibus metals s.r.o. company was used to create a heterogeneous weldment using the MIG LSC method. It is the most widely commercially used clean titanium, providing an excellent balance of strength and ductility. This material is tough and easily weldable. The second basic material for the welding was austenitic chromium-nickel unstabilized steel labelled as $\mathrm{X} 5 \mathrm{CrNi18}-10$ (according to the ČSN EN 10088-1:2015, EN 1.4301 standard) delivered by the JM20 s.r.o. company. Dimensions $(\mathrm{mm})$ of these materials can be seen in Fig. 1 .

Traditional welding method of MIG to weld manganese steel was attempted by Bernát et al. (2013), but weld quality was not optimal. Therefore, innovative welding method MIG LSC was selected for the purposes of this experiment, which was designed by Fronius in order to increase the quality of welded joints. Four welding electrodes were used for MIG LSC welding.

Types of welding electrodes:

1. Titanium electrode (AWS A 5.16 ERTi-1): chemical composition - 99.375\% Ti, 0.25\% Fe, 0.25\% O, 0.08\% C, $0.03 \% \mathrm{~N}, 0.015 \% \mathrm{H}$.

2. Stainless electrode (1.4316): chemical composition $69.22 \% \mathrm{Fe}, 19 \% \mathrm{Cr}, 10 \% \mathrm{Ni}, 1.7 \% \mathrm{Mn}, 0.08 \% \mathrm{C}$.

3. Fe electrode (1.5130): chemical composition $-97.32 \% \mathrm{Fe}$, $1.65 \% \mathrm{Mn}, 0.95 \% \mathrm{Si}, 0.08 \% \mathrm{C}$.

Table 2 Parameters of welding equipment Fronius TPS $400 \mathrm{i}$

\begin{tabular}{|l|c|}
\hline Electrode feed speed & $9.0 \mathrm{~m} \cdot \mathrm{min}^{-1}$ \\
\hline Welding current & $104 \mathrm{~A}$ \\
\hline Welding voltage & $17.5 \mathrm{~V}$ \\
\hline Arc length correction & 0.0 \\
\hline Pulse/dynamics correction & -1.0 \\
\hline Arc length stabilisation & 0.5 \\
\hline Frequency & $3.0 \mathrm{~Hz}$ \\
\hline Gas flow & $15.0 \mathrm{I} \cdot \mathrm{min}^{-1}$ \\
\hline
\end{tabular}

4. CuSi3 electrode (S Cu 6560): chemical composition - 97\% $\mathrm{Cu}$ and $3 \% \mathrm{Si}$.

In all cases, protective atmosphere of the welding bath contained $100 \%$ argon due to a high gas absorption rate of titanium at temperatures exceeding $600{ }^{\circ} \mathrm{C}$.

The MIG LSC - low spatter control welding method was used to melt the additional material in the form of an electrode with the diameter of $1 \mathrm{~mm}$. This is an arc control method for minimum spraying. From a technological point of view, it is soldering by means of an electrical arc as a heat source in order to melt the additional material. For this reason, term welding was utilized in the paper. Table 2 shows welding parameters of equipment Fronius TPS 400i (supplier Austria - Wels) - values given come from the welding device records.

\section{Results and discussion}

Cracks occurred in welds due to the formation of brittle intermetallic compounds between $\mathrm{FeTi}$ and $\mathrm{Fe} 2 \mathrm{Ti}$ when using both titanium and corrosion-resistant electrodes (Figs. $2 \mathrm{a}, 2 \mathrm{~b})$. Other adverse effects included great difference of the thermal expansion coefficient in the additional material and basic materials. Fig. 2 shows cracks in welds between the additional material (stainless electrode; titanium electrode) and one of the basic materials (titanium).

When a Fe electrode was used, the weld broke off completely after a few seconds and material was broken down due to an extreme internal stress caused by the large differences in cooling and subsequent shrinking of different metals (Fig. 2c). These metals have different thermal expansion coefficient. The only electrode, by means of which a permanent heterogeneous joint was achieved, was CuSi3 electrode. Considering the samples in which a crack occurred in the weld (Fig. 2a, 2b, 2c), they have not been submitted to tensile tests, since these were not welded. Samples that were successfully welded were submitted to tensile test in order to observe their mechanical properties. All 10 successfully welded samples showed almost identical course of tensile diagram. The best results achieved in the tensile test using CuSi3 electrode are shown on an example of selected sample in Fig 3.

Representative sample was selected for the best properties. At point B, Fig. 3 shows the maximum stress needed to break the weldment, which amounted to $98 \mathrm{MPa}$.

Tensile strength of basic non-welded titanium material is $345 \mathrm{MPa}$ and tensile strength of the basic non-welded stainless steel material is $520 \mathrm{MPa}$. These values are given to compare the mechanical properties of non-welded base materials. Decrease in weld tensile strength was caused by welding, which adversely affected the material mechanical properties. Further negative effects of welding included the heterogeneity of the joint materials. Despite this, the 

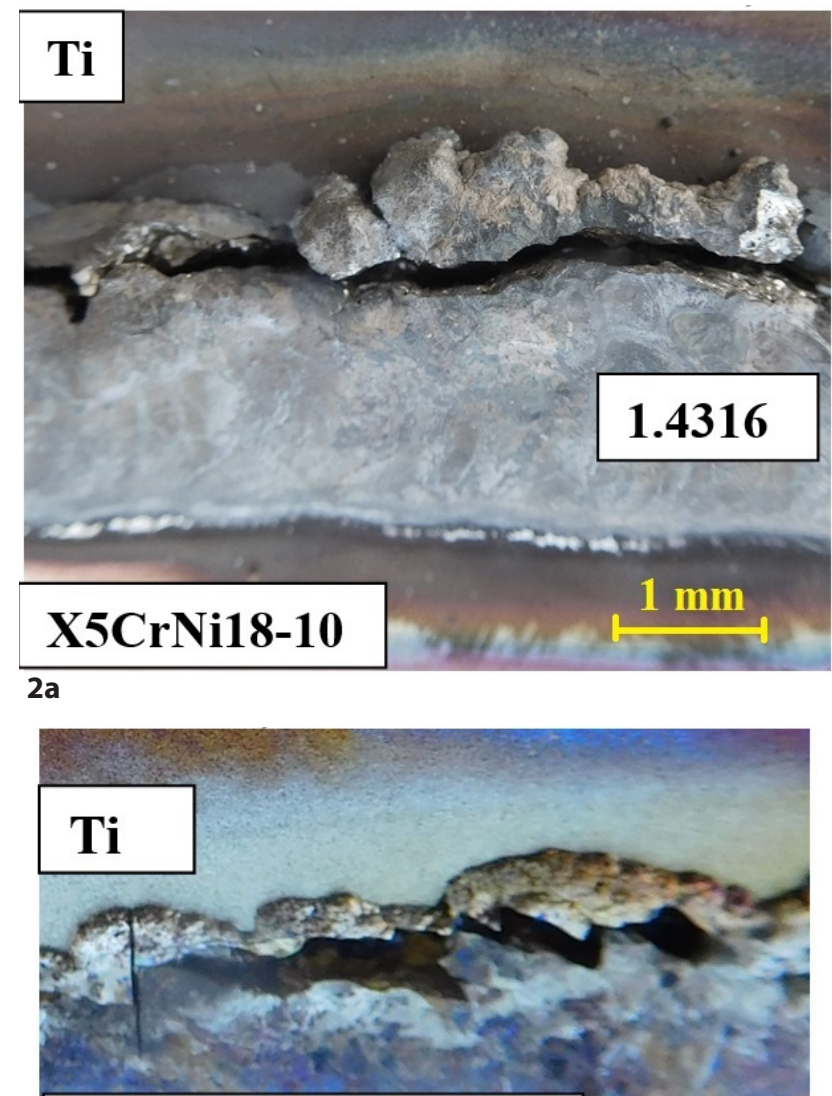

AWS A 5.16 ERTi-1

X5CrNi18-10

2b

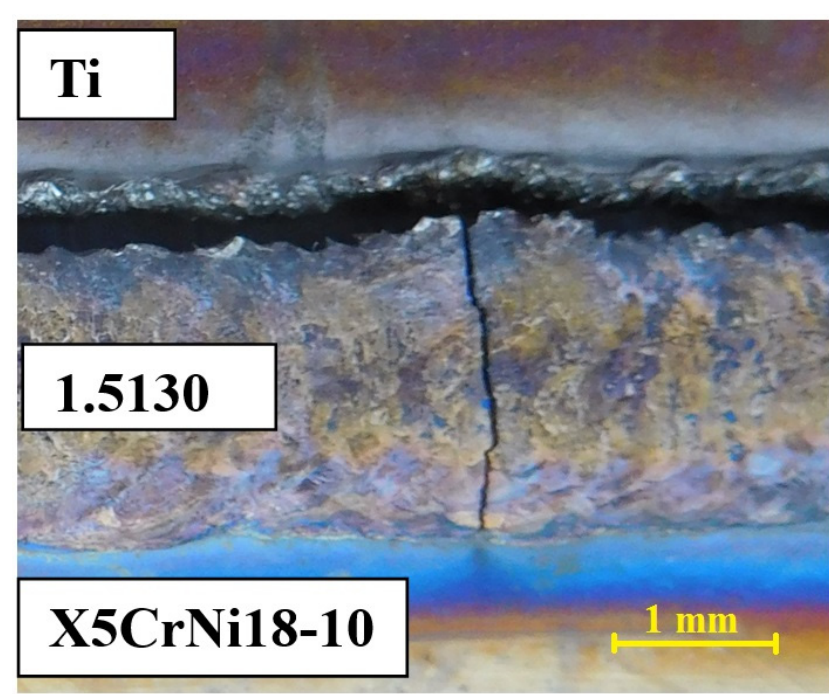

2c

Fig. 2 Cracks in welds: $2 a$ - stainless electrode 1.4316; $2 \mathrm{~b}$ titanium electrode (AWS A 5.16 ERTi-1); 2c - Fe electrode

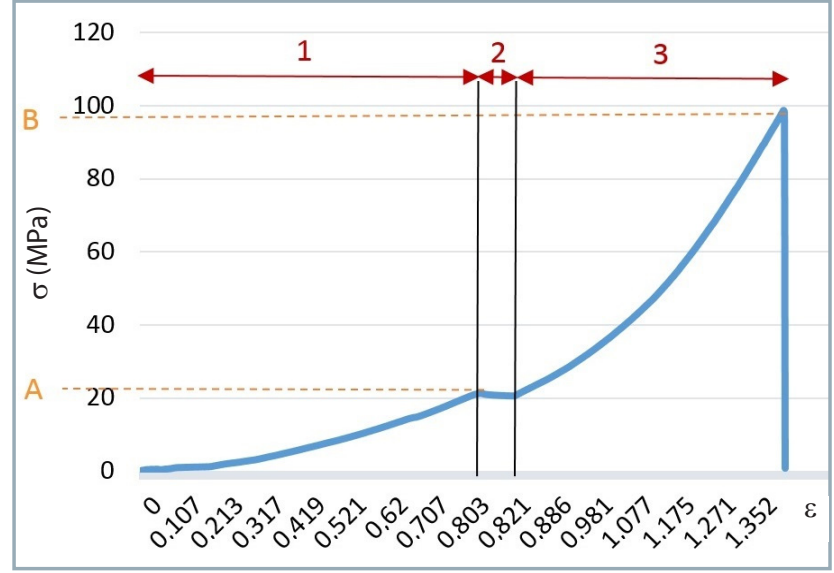

Fig. 3 Tensile test results: A (stress on yield strength) = $21 \mathrm{MPa}$; (stress on strength) $=98 \mathrm{MPa}$

1 - flexible deformation area; 2 - yield strength; 3 - plastic deformation area

welding was successful. Relative elongation of epsilon of the welded joint at the break amounted to 1.35, which represents $135 \%$ of original length of welded joint. Point $A$ shows yield stress amounting to $21 \mathrm{MPa}$. In terms of area 1, only flexible deformation occurs; area 2 shows yield stress and area 3 shows plastic deformation. Fracture was observed in static tensile test of the weld joint. Samples were further observed through metallographic analysis conducted by Honeywell. Microstructure etching was produced using nitric acid. Welding zone microstructure in Fig. 4 consists of a metal (stainless steel X5CrNi10-10), diffusion layer of $0.4 \mathrm{~mm}$ and additional material (CuSi3) consisting of copper and copper silicate. Copper atoms penetrate the steel along the grain boundaries, creating a connection in the area of surface layers.

In regards to the high rate of titanium gas absorption $(\mathrm{N}, \mathrm{O}, \mathrm{H})$ at temperatures exceeding $600{ }^{\circ} \mathrm{C}$, all methods not using a special argon protection, vacuum soldering or a special flux can be excluded for titanium soldering. Titanium reacts very well with melted metals, producing solid solutions with aluminium and carbon. Elements such as $\mathrm{Cu}, \mathrm{Cr}, \mathrm{Fe}, \mathrm{Mn}, \mathrm{Ag}, \mathrm{Co}, \mathrm{Si}$ and $\mathrm{Sn}$ have a limited solubility in both $\alpha$ and $\beta$ phases of titanium. In fusion with titanium, they form an equilibrium diagram with the eutectoid.

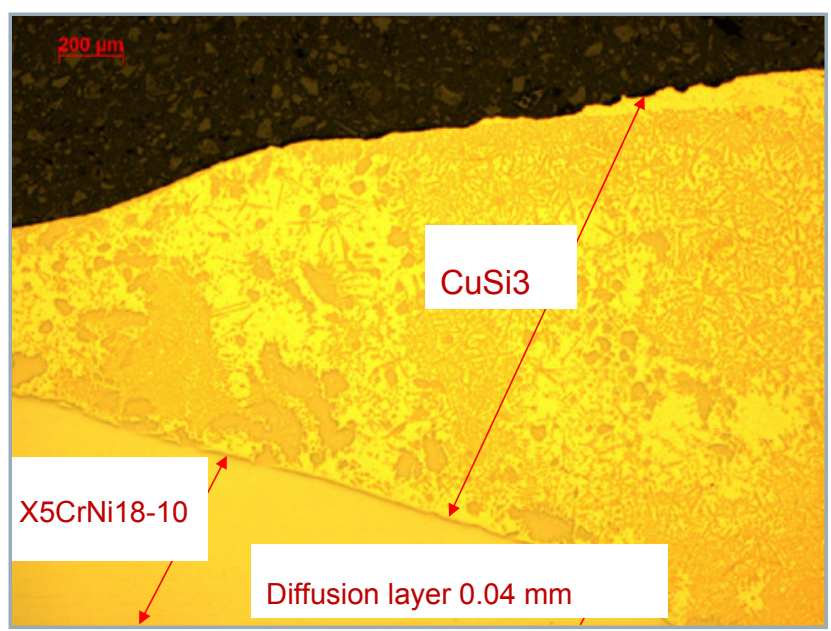

Fig. 4 Welding zone microstructuredeformation area 
Therefore, at an equilibrium state, $\beta$ phase falls into a solid solution and $\gamma$ phase becomes enriched by an alloy. As the content of mentioned elements increases, temperature of the recrystallization also increases, resulting in expansion of $\gamma$ phase stability. The maximum $\mathrm{Cu}$ solubility $(1.5 \%)$ in $\mathrm{Ti}$ is achieved at temperature of $798{ }^{\circ} \mathrm{C}$. At temperature range of $400-600{ }^{\circ} \mathrm{C}$, only $0.4-0.6 \%$ of $\mathrm{Cu}$ is dissolved in $\mathrm{Ti}$. At temperatures below $300{ }^{\circ} \mathrm{C}$, this solubility changes only a little. Eutectoid arises at the $\mathrm{Cu}$ content of $7 \%$. Since $\mathrm{Cu}$ forms a number of intermediary phases with $\mathrm{Ti}$, it is not a suitable material for soldering. The $\mathrm{Cu}$ content in silver solders should be as low as possible, so that soldering at temperatures below $98{ }^{\circ} \mathrm{C}$ might be possible (Mousavi and Sartangi, 2008). If the material is specified as difficult to weld by the manufacturer, it is recommendable to use a CuSi3 electrode. It is possible to achieve good results using this electrode, e.g. in welding of zinc-coated steel sheets with pure zinc or zinc-aluminium (Poláková et al., 2017; Matsui, 1998). Similarly to results obtained by Černý et al. (2016b), no visual external weld defects were detected and weld quality was positively evaluated. Typical tiny spheres that are always caused by molten metal splashes have been found in the immediate vicinity of the weld.

\section{Conclusion}

Due to its high strength to weight ratio, titanium and its alloys are suitable for use in modern industry. Another valued property of titanium is its corrosion resistance (Boyer, 1996). Commercially pure titanium was successfully processed during the exhaust pipe and muffler manufacturing process. This material is used for its good mechanical properties, chemical resistance and for its high quality (and desired) surface appearance.

High wear resistance of titanium and its alloys can be useful e.g. in engine intake valves. Titanium is also resistant to cyclic stress and high temperatures (due to its high melting point). These advantages can be useful e.g. in engines with higher power, not only motorcycles (Fujii et al., 2003). Many industries use a combination of corrosion-resistant steel with titanium. Creating heterogeneous joints in materials with different physical and mechanical properties is always problematic (Moravec et al., 2017). In experiment presented, CuSi3 electrode showed the best results, since it was the only electrode type, by means of which a permanent joint was achieved. Utilization of other electrodes was completely unsuccessful. Therefore, hypothesis presented by Chen et al. (2014) in terms of how difficult it is to weld titanium alloys with steel due to large differences in thermal, physical and chemical properties has been confirmed. Results obtained are in line with Pardal et al. (2016), confirming that it is possible to join a stainless steel and Ti by means of CuSi3 welding electrode utilizing a protective atmosphere of clear argon. The maximum tensile strength achieved by means of MIG LSC welding was $98 \mathrm{MPa}$. Experiment results showed that hypothesis presented by Mousavi and Sartangi (2008) that $\mathrm{Cu}$ is not suitable as material for soldering of titanium joints - has not been confirmed.

\section{Acknowledgement}

The research has been supported by the project TAČR GAMA TG02010074 (part 201801) - PARKISS.

\section{References}

BERNÁT, R. - ZÁLEŽÁK, Z. - KECSKÉS, N. - BLAŠKO, P. 2013. Assessing the weld quality of manganese steel. In Acta Technologica Agriculturae, vol. 16, no. 4, pp. 99-102.

BOYER, R. R. 1996. An overview on the use of titanium in the aerospace industry. In Materials Science and Engineering, vol. 213, no. 1-2, pp. 103-114.

ČERNÝ, M. - DOSTÁL, P. - MAZAL, P. - ŠUSTR, M. 2016a. Verification of the quality of the weld when utilising the MAG/CO 2 method. In Acta Universitatis Agriculturae et Silviculturae Mendelianae Brunensis, vol. 64, no. 1, pp. 31-42.

ČERNÝ, M. - DOSTÁL, P. - ŠUSTR, M. 2016b. Visualization of the coated electrode welding. In Acta Universitatis Agriculturae et Silviculturae Mendelianae Brunensis, vol. 64, no. 1, pp. 43-51.

ČSN EN 10088-1: 2015. Stainless Steel - Part 1: Stainless Steel Overview. Praha: Český normalizační institut. (In Czech: Korozivzdorné oceli - Část 1: Přehled korozivzdorných ocelí).

FUJII, H. - TAKAHASHI, K. - YAMASHITA, Y. 2003. Application of titanium and its alloys for automobile parts. In Nippon steel technical report, Shinnittetsu giho, vol. 378, no. 88, pp. 62-67.

HLUCHÝ, M. - KOLOUCH, J. 2002. Engineering Technology 1 - Part 1: Materials Science. $1^{\text {st }}$ ed., Praha : Scientia, spol. s r. o. 266 pp. ISBN 8071832626. (In Czech: Strojírenská technologie 1 - 1. díl Nauka o materiálu).

HLUCHÝ, M. - MODRÁČEK, O. - PAŇÁK, R. 2002. Engineering Technology 1 - Part 2: Metallography and Heat Treatment. Praha : Scientia, spol. s r. O., 173 pp. ISBN 8071832650. (In Czech Strojírenská technologie 1 - 2. Díl: Metalografie a tepelné zpracování).

CHEN, S. - ZHANG, M. - HUANG, J. - CUI, C. - ZHANG, H. - ZHAO, X. 2014. Microstructures and mechanical property of laser butt welding of titanium alloy to stainless steel. In Materials \& Design, vol. 53, pp. 504-511.

MATSUI, H. 1998. Arc welding technologies of galvanized steel sheet for automotive underbody. In Proceedings of $4^{\text {th }}$ International Conference on Zinc and Zinc Alloy Coated Steel Sheet. Japan : The Iron and Steel Institute, pp. 778-784.

MORAVEC, J. - DIKOVITS, M. - BEAL, M. C. - NOVAKOVA, I. CHANDEZON, R. - SOBOTKA, J. 2017. Selection of the proper diffusion welding parameters for the heterogeneous joint Ti grade 2/AISI 316L. In Manufacturing Technology, vol. 2, pp. 231-237.

MOUSAVI, S. A. - SARTANGI, P. F. 2008. Effect of post-weld heat treatment on the interface microstructure of explosively welded titanium-stainless steel composite. In Materials Science and Engineering: vol. 494, no. 1-2, pp. 329-336.

PARDAL, G. - GANGULY, S. - WILLIAMS, S. - VAJA, J. 2016. Dissimilar metal joining of stainless steel and titanium using copper as transition metal. In The International Journal of Advanced Manufacturing Technology, vol. 86, no. 5-8, pp. 1139-1150.

POLÁKOVÁ, N. - DOSTÁL, P. - ČERNÝ, M. - VOTAVA, J. - DOBROCKY, D. 2017. Effect of heat treatment of CMT weld on its mechanical properties. In: MendelNet Proceedings of International PhD Students Conference. Mendel University in Brno, pp. 802-807. ISBN 9788075095299.

SAGAR, D. B. A. - VIKAS, B. - SAHA, B. - NARASIAH, N. - JAYAPAL, P. - RAM, G. D. J. - RAO, M. S. K. 2018. Study of microstructure and mechanical properties of friction welded metastable beta titanium alloy titan 1023. In Materials Today Proceedings, vol. 5, no. 9, pp. 20760-20768.

ŠUSTR, M. - DOSTÁL, P. - ZAČAL, J. 2016. The acoustic emission for monitoring the hardness of the cold metal transfer weld. In Acta Universitatis Agriculturae et Silviculturae Mendelianae Brunensis, vol. 64, no. 2, pp. 543-547.

TALBOT, D. E. J. - TALBOT, J. D. R. 2019. Corrosion Science and Technology. $2^{\text {nd }}$ ed., Florida: CRC Press LLC. 432 pp. ISBN 1420049887. 